\title{
The borderline between cluster headache and migraine: does cluster-migraine exist?
}

\author{
C Lisotto ${ }^{1 *}$, F Mainardi $^{2}$, F Maggioni ${ }^{1}, G$ Zanchin $^{1}$ \\ From The European Headache and Migraine Trust International Congress \\ London, UK. 20-23 September 2012
}

\section{Introduction}

Cluster headache $(\mathrm{CH})$ is a well definite disorder. When the attacks fulfil all but one of the criteria for $\mathrm{CH}$, probable $\mathrm{CH}$ should be diagnosed, requiring one of the following conditions: 1 ) attacks lasting $>180$ minutes, 2) attacks without autonomic local signs or restlessness, 3) sporadic (less than one every other day) attacks. Background In the past "cluster-migraine" was considered an atypical variant of $\mathrm{CH}$, but this entity was never categorized.

\section{Methods}

Since 1996 we have observed 251 patients with $\mathrm{CH}$. Out of these cases, 33 (19 males and 14 females) could not fulfil all criteria for $\mathrm{CH}$ and have been followed-up for at least 5 years.

\section{Results}

We could distinguish 4 different subgroups. For 3 subgroups the unfulfilled criteria were: 1 ) pain duration $>3$ hours, ranging 4-8 hours (6 cases), 2) absence of autonomic signs or restlessness (5 cases), 3) sporadic attacks, with no cluster periodicity (10 cases). We could also identify a fourth subgroup of 12 patients without cluster pattern and attack duration lasting 3-5 hours, borderline between $\mathrm{CH}$ and migraine without aura (MO). Moreover, the coexistence of $\mathrm{MO}$ and $\mathrm{CH}$ was noted in 8 cases. The first subgroup overlaps with probable MO. Criteria are not fully met and patients are labelled as probable $\mathrm{MO}$ or probable $\mathrm{CH}$, either of which could have features of the other. The second and third subgroups meet criteria for probable $\mathrm{CH}$. The fourth subgroup does not fulfil criteria either for probable $\mathrm{CH}$ or probable $\mathrm{MO}$, therefore the old definition of cluster-migraine may be still appropriate, even if this term might be considered a regression to the time when $\mathrm{CH}$ was considered a variant of migraine

${ }^{1}$ Headache Centre, University of Padua, Italy

Full list of author information is available at the end of the article
[1]. Interestingly, 3 patients in the third subgroup evolved over time into a typical $\mathrm{CH}$.

\section{Conclusion}

Patients sometimes present with clinical scenarios having characteristics of both $\mathrm{MO}$ and $\mathrm{CH}$, but either do not fully meet criteria for either disorder or have no sufficient symptoms to allow both diagnoses to be present. These occasions may account for the controversial form of cluster-migraine.

\section{Author details}

${ }^{1}$ Headache Centre, University of Padua, Italy. ${ }^{2}$ Headache Centre, Hospital of venice, Italy.

\section{Published: 21 February 2013}

\section{Reference}

1. Nelson FN: Cluster migraine - an unrecognized common entity. Can Med Assoc J 1970, 103:1026-1030.

doi:10.1186/1129-2377-14-S1-P42

Cite this article as: Lisotto et al:: The borderline between cluster headache and migraine: does cluster-migraine exist? The Journal of Headache and Pain 2013 14(Suppl 1):P42.

Submit your manuscript to a SpringerOpen ${ }^{\circ}$ journal and benefit from:

- Convenient online submission

- Rigorous peer review

- Immediate publication on acceptance

- Open access: articles freely available online

- High visibility within the field

- Retaining the copyright to your article

Submit your next manuscript at $>$ springeropen.com
(C) 2013 Lisotto et al; licensee Springer. This is an Open Access article distributed under the terms of the Creative Commons Attribution License (http://creativecommons.org/licenses/by/2.0), which permits unrestricted use, distribution, and reproduction in any medium, provided the original work is properly cited. 